\title{
Influence of oligofructose-enriched inulin on survival of microencapsulated Lactobacillus casei 01 and adhesive properties of synbiotic microparticles
}

\author{
Tanja Petreska Ivanovska ${ }^{1 *}$, Zoran $Z_{\text {hivikj }}{ }^{1}, K_{\text {ristina Mladenovska }}^{2}$, \\ Lidija Petrushevska-Tozi ${ }^{1}$ \\ ${ }^{1}$ Institute of Applied Biochemistry, Faculty of Pharmacy, University "Ss. Cyril and Methodious", \\ Mother Theresa 47, Skopje, Macedonia \\ ${ }^{2}$ Institute of Pharmaceutical Technology, Faculty of Pharmacy, University "Ss. Cyril and Methodious", \\ Mother Theresa 47, Skopje, Macedonia
}

Received: March 2015; Accepted: April 2015

\begin{abstract}
Lactobacillus casei 01 was co-encapsulated with the prebiotic oligofructose-enriched inulin at different concentrations to investigate the efficiency of the prebiotic for improving the probiotic viability. Prebiotic effect on the probiotic survival under microencapsulation conditions by spray- and freeze-drying and storage stability of encapsulated living cells at $4{ }^{\circ} \mathrm{C}$ during period of 8 weeks was evaluated. Adhesiveness of $L$. casei 01 loaded microparticles to pig mucin was investigated in vitro to estimate the role of microencapsulation for improving the cell adhesion ability. The microparticles produced with $3 \% w / w$ oligofructose-enriched inulin showed higher initial count, while oligofructose-enriched inulin applied at $1.5 \% \mathrm{w} / \mathrm{w}$ resulted in better protection of $L$. casei 01 under storage conditions. Further, it has been observed significantly increased pig mucin binding to microparticles compared to free probiotic cells in buffer solutions simulating GI conditions, during $24 \mathrm{~h}$ incubation. Hence, cell microencapsulation beside enhanced viability may allow prolonged residence time of the probiotic cells in the lower intestine through excellent muco-adhesive properties of the encapsulating materials. The results suggest synbiotic chitosan-Ca-alginate microparticles as convenient delivery system capable to ensure effective cell concentration in the lower intestine where probiotic colonization is dominant.
\end{abstract}

Keywords: oligofructose-enriched inulin, Lactobacillus casei, synbiotic microparticles, muco-adhesion

\section{Introduction}

Functional foods containing naturally or added probiotics and/or prebiotics provide physiological or metabolic benefits by regulating the gut microbiota composition and stability. The health-beneficial properties of these bioactive compounds have made functional foods increasingly popular in food markets (Peshev and Van den Ende, 2014).

* Tel.: +3892 3123062; fax: +38923123054

tpetreska@ff.ukim.edu.mk
Probiotics that belong mainly to the genera Lactobacillus and Bifidobacterium can alter the microbial balance aiding the host through several mechanisms, such as production of pathogen-inhibitory substances, competition with pathogenic bacteria for epithelial adhesion sites, nutrient competition and production, degradation of toxins and toxin receptors and modulation of immune and nonspecific host responses (Prakash et al., 2011). Examples of health benefits attributed to probiotics range from treatment of Helicobacter pylori infections (Gotteland et al., 2008) and antibiotic-associated diarrhea (Marteau et al., 
2001), inflammatory bowel diseases (Gentschew and Ferguson, 2012), irritable bowel syndrome (Almansa et al., 2012), allergic diseases such as eczema and atopic dermatitis (Wickens et al., 2008), delaying of aging in humans (Duncan and Flint, 2013), modulating blood lipid levels (Omar et al., 2013) to prevention of gastrointestinal cancers (Orlando and Russo, 2012).

The most important aspect of a probiotic to provide its health benefits is to remain viable during processing and storage of food products and also after consumption. The final probiotic product that serves as a probiotic delivery system should contain at least $10^{6}-10^{7}$ live microorganisms per $\mathrm{g}$ or $\mathrm{mL}$ before consumption (Nualkaekul et al., 2012). Viability loss may be reduced by immobilization or microencapsulation of probiotic bacteria in a polymer matrix (Mitropoulou et al., 2013). Along with survival, binding of probiotic bacteria to intestinal cells is often the main feature studied. Adhesion to the intestinal epithelium is an outcome property of probiotics that may influence the residence time of the bacteria in the intestinal tract (MuñozProvencio et al., 2009) and is considered to be associated with documented health effects for the host. Binding of microbial cell-surface molecules to the mucus layer is possible mechanism of bacterial adherence based on non-specific physical interactions which then enable specific interactions between proteins and mucin-bound oligosaccharides (Van Tassell and Miller, 2011). Adhesive characteristics of lactobacilli vary considerably among strains and species depending on physicochemical structure of the cell membrane, conformation of cell surface macromolecules and susceptibility to external factors (Deepika and Charalampopoulos, 2010). Hence, microencapsulation using polymer materials with convenient biochemical properties may contribute to improved physicochemical characteristics of the cell i.e. muco-adhesion along with improved cell survival. Hydrophilic polymers such as alginate and chitosan possess favorable muco-adhesive properties providing enhanced in situ delivery of probiotic bacteria in the gastrointestinal tract (Chen et al., 2013).

Prebiotic supplementation to probiotic products or formulations may potentially be useful for enhancing the probiotic survival during processing (Corcoran et al., 2004) and storage (Capela et al., 2006). Prebiotics are defined as "selectively fermented ingredients that result in specific changes in the composition and/or activity of the gastrointestinal microbiota, thus conferring benefit upon host health" (ISSAP, 2008). They pass through the upper gastrointestinal tract undigested, entering the large bowel where can influence the growth of microbial populations and the production of short chain fatty acids (SCFAs) (Macfarlane et al., 2006). Acetate, propionate and butyrate, as the main SCFAs, and lactate, as an important intermediate in the formation of SCFAs, are thought to be beneficial to host health. They have been found to alter gut integrity and to possess anti-inflammatory, antimicrobial and anti-carcinogenic effects, thus playing significant role in maintenance of gut and immune homeostasis (Tan et al., 2014). The most widely studied prebiotics which can be selectively used by bifidobacteria and lactobacilli as substrates are fructooligosaccharide (FOS), galacto-oligosaccharide (GOS) and inulin (Watson et al., 2013). Inulin as polysaccharide and FOS as oligosaccharide are naturally occurring inulin type fructans with similar structure build up of $\beta 2 \rightarrow 1$ linkages. These carbohydrates have generally been distinguished by the polymerization level, while oligofructose and FOS are products of the inulin hydrolysis.

A selective inclusion of probiotic and prebiotic in accordance with the desired health effects would provide an effective synbiotic. The presence of the prebiotic compound may improve the probiotic survival during processing and storage of the products and also after consumption. Co-encapsulation of probiotics, L. rhamnosus, L. acidophilus, L. casei and Bifidobacterium spp. with prebiotics such as FOS (Raftilose P95) improved their viabilities at $4{ }^{\circ} \mathrm{C}$ for 4 weeks of product storage (Capela et al., 2006). Freshcut apple wedges with synbiotic properties and counts of probiotic bacteria comparable to commercially available dairy products (ca. $10^{8} \mathrm{cfu} / \mathrm{g}$ ) have been developed using L. rhamnosus $\mathrm{GG}$ as probiotic and inulin and oligofructose as prebiotics (Rößle et al., 2010). Application of prebiotics as co-components for microencapsulation of probiotics or immobilization of probiotics in prebiotic edible films has also conferred a beneficial effect on cell viability (Nazzaro et al., 2009; Fritzen-Freire et al., 2012; Krasaekoopt and Watcharapoka, 2014; Petreska Ivanovska et al., 2014a; Sathyabama et al., 2014; Soukoulis et al., 2014). Although, significant number of synbiotic combinations confirms the synergistic effect of the prebiotic in enhancing probiotic survival and growth in vitro and in vivo, literature evidences are still limited (Duncan and Flint, 2013).

Our previous investigations (Petreska Ivanovska et al., 2012b; 2014a) indicated that the applied spray-drying method and combination of chitosan and alginate crosslinked with $\mathrm{CaCl}_{2}$ as protective agents in presence of $\mathrm{FOS}$ from chicory (DP > 10) $(1.5 \% \mathrm{w} / \mathrm{w})$ efficiently preserved the viability of $L$. casei 01 during encapsulation, cold storage and in simulated gastrointestinal conditions. In the present study, we examined the influence of the prebiotic oligofructose-enriched inulin (Synergy 1) on the viability of encapsulated $L$. casei 01 during microencapsulation by spray-drying and subsequent cold storage during 8 weeks. In addition, adherence capacity of the L. casei 01 loaded microparticles containing Synergy 1 in concentration showing better effect on the probiotic viability was studied in vitro.

\section{Materials and methods}

\section{Materials}

Freeze-dried probiotic culture of Lactobacillus paracasei subsp. paracasei with commercial name FD-DVS 
Lactobacillus casei 01 was purchased from Chr. Hansen, Denmark. The prebiotic, oligofructose-enriched inulin (Orafti ${ }^{\circledR}$ Synergy 1) which is the mixture of oligofructose (DP 2-8) and long-chain inulin fraction (DP 1060) was supplied from Orafti-Rue L. Maréchal, Tienen, Belgium. Sodium alginate (Protanal LF 10/60 LS, fG 35$45 \%$ ), which was kindly donated by IMCD, FMC BioPolymer (Ayrshire, UK), was used as an encapsulating agent for manufacturing of L. casei 01 loaded microparticles. Chitosan with deacetylation degree $\geq 85 \%$ and low viscosity 342 (viscosity of $1 \% \mathrm{v} / \mathrm{v}$ solution in acetic acid 20-100 $\mathrm{mPa} s, \mathrm{M}_{\mathrm{w}} 150 \mathrm{kDa}$ (France Chitine, Marseille, France) was used for coating of spray-dried microparticles, while the cross-linking procedure was performed with $\mathrm{CaCl}_{2}$ (Merck, KGaA, Darmstadt, Germany). The Man Rogosa Sharpe (MRS) broth, MRS agar and peptone water used for growth and enumeration of $L$. casei 01 were purchased from Merck, KGaA, Darmstadt, Germany. Pig mucin (Mucin from porcine stomach, Type II, bond sialic acids: $1 \%$ ) used for in vitro determination of adherence properties of L. casei 01 and prepared microparticles was supplied from Sigma-Aldrich, Co., St. Louis, USA.

\section{Preparation of probiotic culture}

Freeze-dried culture of $L$. casei 01 was inoculated in $10 \mathrm{~mL}$ MRS broth at $37^{\circ} \mathrm{C}$ under aerobic conditions overnight to reach the cell concentration at least $12 \log \mathrm{CFU}$ $\mathrm{mL}^{-1}$. The next day, cells were harvested by centrifugation at $1500 \mathrm{~g}$ for $10 \mathrm{~min}$ and washed with sterile peptone water $(0.1 \% w / v)$.

\section{Microencapsulation of probiotic and prebiotic}

Probiotic/synbiotic chitosan-Ca-alginate microparticles were prepared according to the method described by Petreska-Ivanovska et al. (2014a). The feed suspension was prepared of carrier agent sodium alginate $(4 \% \mathrm{w} / \mathrm{w})$ and previously prepared probiotic suspension. To produce synbiotic microparticles, to the probiotic-alginate dispersion, the prebiotic, oligofructose-enriched inulin at respective concentrations of $0,1.5,3$, and $5 \% w / w$, was added. Then, the mixture was spray-dried (Büchi Mini Spray Dryer B-290, Flawil, Switzerland) at following conditions: constant air inlet temperature of $120{ }^{\circ} \mathrm{C}$ and outlet temperature at $58 \pm 3{ }^{\circ} \mathrm{C}$, flow rate $6 \mathrm{ml} / \mathrm{min}$, nozzle diameter $0.7 \mathrm{~mm}$, aspirator pressure $90 \%$ and atomizer pressure $600 \mathrm{Nlh}^{-1}$. Dried powder samples were slowly added to a $5 \% \mathrm{w} / \mathrm{w} \mathrm{CaCl}_{2}$ and $0.5 \% \mathrm{w} / \mathrm{w}$ chitosan dissolved in $1 \% \mathrm{v} / \mathrm{v}$ acetic acid, under continuous stirring. The microparticles were allowed to stir on a magnetic stirrer for at least $3 \mathrm{~h}$ at $25{ }^{\circ} \mathrm{C}$. Then, the particles were separated by centrifugation at $1500 \mathrm{x} g$ for $10 \mathrm{~min}$, rinsed with sterile saline solution and then freeze-dried at $0.070 \mathrm{mbar}$ and $-50{ }^{\circ} \mathrm{C}$ for 24 h (FreeZone Freeze Dry System, Labconco, Kansas City, USA).

\section{Enumeration of encapsulated L. casei 01}

Viability of encapsulated and co-encapsulated L. casei during microencapsulation and in storage conditions was determined using plate-count method. One gram of particles was suspended in $9 \mathrm{~mL}$ phosphate buffer solution $(\mathrm{pH}$ 6.9) at room temperature and then allowed to stand until complete release of the probiotic cells. Then, sequential dilutions were prepared using $0.1 \% \mathrm{w} / \mathrm{v}$ peptone water in order to achieve countable cell numbers. Quantitative determination of viable cells was performed on selective MRS agar after $72 \mathrm{~h}$ aerobic incubation at $37^{\circ} \mathrm{C}$. Enumeration of viable cells was performed in triplicates counting the plates with 30-300 colonies and the average of the results was expressed as colony-forming units (CFU) per $\mathrm{g}$ of sample. The obtained results calculated in $\mathrm{CFU} \mathrm{\textrm {g } ^ { - 1 }}$ were converted to $\log \mathrm{CFU} \mathrm{g}^{-1}$.

In vitro analysis of the adhesive properties of L. casei 01 and synbiotic loaded microparticles

Adherence capacity of L casei 01 cells, synbiotic and empty microparticles was tested by in vitro adsorption studies using pig mucin (PM) in accordance to the method described by Glavas Dodov et al. (2009). To determine the bioadhesive interactions of the free cells, synbiotic and empty microparticles, $5 \mathrm{~mL}$ of the pig mucin suspension was mixed with the equal volume of cell or microparticle suspension and incubated in different buffer solutions $(\mathrm{pH}$ 2.0, 4.5, 6.8, and 7.4; Ph.Eur. 4). After 1, 3, 5, and $24 \mathrm{~h}$ incubation at $37{ }^{\circ} \mathrm{C}$, the samples were centrifuged $(10 \mathrm{~min}$ at $4000 \mathrm{rpm}$ ), and the remaining free PM in the supernatants was measured UV spectrophotometrically (Perkin Elmer UV/VIS Spectrometer, Lambda 16, Arizona, USA) at $251 \mathrm{~nm}$, since interacted PM was sediment with the cells or particles. The PM binding efficiency of cells or microparticles was calculated using following equation:

$$
\text { PM binding efficiency }(\%)=(\mathrm{Co}-\mathrm{Cs}) / \mathrm{Co} \times 100
$$

Where Co is the initial concentration of PM used for incubation and $\mathrm{Cs}$ is the concentration of free PM determined in the supernatant.

\section{Data analysis}

Mean values of the obtained results were analyzed by two-way ANOVA at a significance level of $p<0.05$.

\section{Results and discussion}

Influence of Synergy 1 on the survival of L. casei 01 during microencapsulation

High temperature, presence of oxygen and high osmotic pressure associated with the drying processes are detrimental for living cells survival (Meng et al., 2008). 
Hydrocolloids as oligosaccharides are might preserve cell viability, allowing hydrogen binding and preventing cell proteins from denaturation (Capela et al., 2006). In order to improve the probiotic survival during microencapsulation, in this study an oligofructose-enriched inulin Synergy 1 was used to co-encapsulate $L$. casei 01 in chitosan-Caalginate microparticles prepared by spray-drying and subsequent freeze-drying. The effect of the prebiotic Synergy 1 on the survival of $L$. casei 01 during microencapsulation when added at concentrations of $1.5,3$, and $5 \% \mathrm{w} / \mathrm{w}$ to a previously optimized formulation of chitosan-Ca-alginate microparticles (Petreska Ivanovska et al., 2014a) was examined and the data are presented in Fig. 1. In a previous study in which survival rate of $L$. casei after co-encapsulation with the prebiotic FOS was studied, used in the same concentrations as Synergy 1, relatively high viability of 11.1-11.2 $\log \mathrm{CFU} \mathrm{g}^{-1}$ after microencapsulation was observed (Petreska Ivanovska et al., 2012b). However, FOS was reported to be less stable oligosaccharide under conditions of low $\mathrm{pH}$ and high temperatures, especially if two factors are combined (Charalampopoulos and Rastall, 2012). For this reason, the prebiotic oligofructose-enriched inulin was used to co-encapuslate $L$. casei 01 and the data related to the probiotic viability after preparation of microparticles and during cold storage were compared. Comprising that oligosaccharides with low degree of polymerization (DP 6-10) are more acceptable by bacteria (Sathyabama et al., 2014), Synergy 1, being a mixture of oligofructose with DP 2-8 and long-chain inulin fraction (DP 10-60), was expected to provide better protection than FOS from chicory (DP $>10)$.

The results obtained pointed that probiotic survival during preparation of the microparticles in the presence of oligofructose-enriched inulin was significantly enhanced $(\mathrm{p}<0.05)$. However, the results for survival rate of $L$. case $i$ 01 in a presence of $1.5-5 \% w / w$ oligofructose-enriched inulin ranging from 11.31-11.38 $\mathrm{log} \mathrm{CFUg}^{-1}$ showed no significant difference $(\mathrm{p}>0.05)$ compared to those of the respective FOS levels, ranging from 11.28-11.33 log CFUg${ }^{1}$. This finding may be explained by the similar structure of both prebiotics. Namely, in a study of Fritzen-Freire and co-workers (Fritzen-Freire et al., 2012), microencapsulated Bifidobacterium BB-12 showed higher initial count (after spray-drying) with encapsulating agent reconstituted skim milk (RSM) and prebiotics inulin or oligofructoseenriched inulin in a ratio $1: 1$, when compared to microcapsules produced with RSM only and with oligofructose. The inulin was reported to act as a thermoprotector for the cells undergoing the drying process. Inulin applied at concentration of $0.5,1$, and $1.5 \%$ was also reported to provide improved survival during microencapsulation of $L$. acidophilus 5 and $L$. casei 01 with alginate and chitosan (Krasaekoopt and Watcharapoka, 2014). However, in the study, an extrusion technique was used to encapsulate the cells. Also, viability of L. rhamnosus GG during air drying was significantly enhanced by glucose-oligosaccharides and polydextrose, whilst inulin was the most effective to control the sub-lethal effects on the cells during storage of prebiotic edible films developed as vehicles for encapsulated L. rhamnosus GG (Soukoulis et al., 2014). Cell viability upon thermal processes is strongly influenced not only by extrinsic factors, but also intrinsic factors such as tolerance of the strain to heat, osmotic and mechanical stresses (Fu and Chen, 2011). Therefore, the preserving effects of the prebiotics for one bacterial strain in the tested conditions could not be extrapolated to other bacterial strains. According to the principal mechanisms of the protective properties of oligosaccharides, primarily through their impact on the glass transition process (Fritzen-Freire et al., 2012), enhanced cell survival is expected when their level in the drying media is increased. However, in the actual study, increased concentration of Synergy 1 from 1.5 to $5 \%$ $w / w$ did not provide increased cell survival or insignificantly improved the survival rate $(p>0.05)$ during the sprayand freeze-drying processes (Fig. 1). Similar behavior was observed when concentrations of FOS were increased from 1.5 to $5 \% w / w$ (Petreska Ivanovska et al., 2012b), suggesting that higher oligosaccharide level in the drying media probably contribute to increased osmotic stress which negatively affects the cell survival. However, when compared to the formulation without prebiotic, enhanced survival of co-encapsulated $L$. casei 01 with $1.5 \% \mathrm{w} / \mathrm{w}$ oligofructoseenriched inulin for approximately $1.2 \operatorname{logs}$ was achieved, confirming the protective role of the prebiotic used.

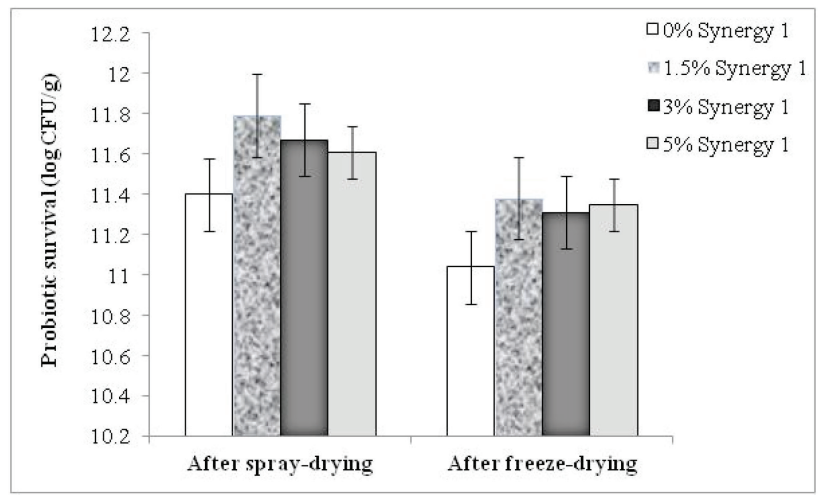

Fig. 1. Survival of Lactobacillus casei 01 during preparation of probiotic/synbiotic microparticles in a presence of different concentrations $(1.5,3$, and $5 \% w / w)$ of the prebiotic Synergy 1 (oligofructose-enriched inulin). Probiotic cell counts in the initial suspension were 12-12.2 $\log \mathrm{CFU} \mathrm{mL}^{-1}$.

\section{Survival of microencapsulated cells during storage}

Addition of the prebiotic oligofructose-enriched inulin during the microencapsulation increased the resistance of L. casei 01 cells to cold storage conditions (Fig. 2). Grad- 
ual decline of the probiotic viability in all examined samples during the whole storage period of 8 weeks was observed. At the 8 th week of storage, the number of probiotic cells encapsulated without prebiotic and with $1.5,3$, and $5 \% \mathrm{w} / \mathrm{w}$ oligofructose-enriched inulin was reduced by $3.55,2.35,2.51$, and $2.35 \operatorname{logs}$, respectively. Equal viability reduction was obtained with 1.5 and $5 \% \mathrm{w} / \mathrm{w}$ oligofructose-enriched inulin, indicating no need of increasing the prebiotic concentration above $1.5 \% w / w$. FOS added in the same formulation at the concentration of $3 \% w / w$ was slightly more effective compared to $1.5 \% \mathrm{w} / \mathrm{w}$, but the cell number reduction using 5\% $w / w$ FOS was even more higher than with $1.5 \% w / w$ (Petreska Ivanovska et al., 2012b). Presence of hydrolytic products of higher oligosaccharides or presence of excess glucose, fructose, and sucrose in the medium inhibited the usage of FOS by the probiotic Lactobacillus paracasei 1195 (Kaplan and Hutkins, 2003). This observation may explain the survival behavior of $L$. casei 01 when the level of oligofructose-enriched inulin is increased from 1.5 to $5 \% \mathrm{w} / \mathrm{w}$. With the comparative analysis of the protective effects of FOS and oligofructose-enriched inulin, each added in a concentration of $1.5 \% \mathrm{w} / \mathrm{w}$, lower viability loss of oligofructose-enriched inulin co-encapsulated L. casei 01 was obtained. Makras et al. (2005) observed fast growth of the probiotic $L$. paracasei subsp. paracasei 8700:2 in the presence of oligofructose and longchain inulin, but the same strain more efficiently degraded the oligosaccharides with short and medium chains such as oligofructose. This finding indicated that certain probiotic strains better utilized short-chain oligosaccharides such as oligofructose ( $\mathrm{DP}<10)$ compared to long-chain oligosaccharides (DP $>10)$. Since FOS from chicory used in our previous study has DP $>10$ (Petreska Ivanovska et al., 2012b), the presence of oligofructose in Synergy 1 was advantageous in terms of maintaining higher viable counts of L. casei 01 during storage of the microparticles. Unlikely to this, greatest stability of encapsulated $L$. rhamnosus GG was detected during cold storage of prebiotic edible films supplemented with inulin (Soukoulis et al., 2014). In the study of Fritzen-Freire et al. (2012), oligofructose-enriched inulin was found to better protect Bifidobacterium BB-12 during storage of the microcapsules produced by spray-drying, although oligofructose showed good protection as well. The divergence of the reported results is difficult to be explained since clear evidences on the specific protective action of the prebiotics such as FOS or inulin for each probiotic has not been provided yet (FritzenFreire et al., 2012).

Further, the lowest concentration of the prebiotic Synergy 1 provided significantly improved survival rate $(\mathrm{p}<$ 0.05 ) of co-encapsulated $L$. casei 01 , thus the concentration of $1.5 \% \mathrm{w} / \mathrm{w}$ seemed to be optimal to co-encapsulate L. casei 01 in chitosan-Ca-alginate microparticles using a spray-drying technique. This level is in accordance with the optimum dose of inulin type fructans ranged from 4-15 $\mathrm{g}$ on a daily basis (Yasmin et al., 2015) in order the prebi- otic to provide bifidogenicity, while avoiding GI adverse effects.

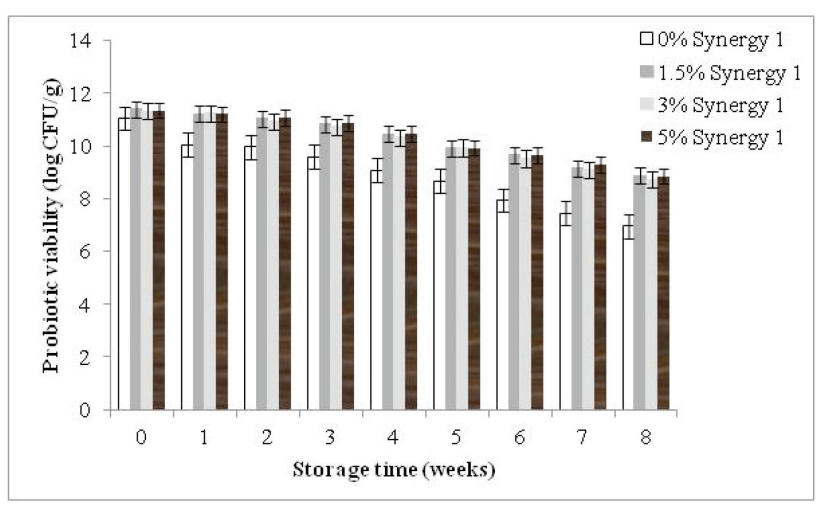

Fig. 2. Viability of Lactobacillus casei 01 encapsulated and co-encapsulated with the prebiotic Synergy 1 (oligofructose-enriched inulin) $(1.5,3$, and $5 \%$ $w / w)$ during 8 weeks of cold storage of the chitosan-Ca-alginate microparticles.

There are set of studies confirming improved stability of co-encapsulated probiotics with inulin, FOS or oligofructose-enriched inulin, but after being added to yoghurts or fruit juices (Capela et al., 2006; Krasaekoopt and Watcharapoka, 2014; Nazzaro et al., 2009; Petreska Ivanovska et al., 2014a). However, the cell survival during the storage of the food products may be additionally influenced by possible interactions of the food components with the bioactive compounds added or encapsulating materials.

\section{Adherence capacity of non-encapsulated L. casei 01 and synbiotic loaded microparticles}

Selection criteria of probiotics include bacterial ability to adhere to the intestinal mucosa, while proper selection of biopolymers applied to encapsulate the probiotics may exhibit improved muco-adhesion. In this study, biodegradable synbiotic chitosan-Ca-alginate microparticles were prepared using spray-drying method and subsequent freeze-drying in order to take advantage of the protective and muco-adhesive effects of polymers for improved intestinal delivery of the probiotic $L$. casei 01 . Since zeta potential of $L$. casei 01 cells measured in $\mathrm{pH} 6.8$ was found to be negative (-16.4 $\pm 0.7 \mathrm{mV}$ ) (Petreska Ivanovska et al., 2014a), indicating poor affinity to adhere to the negatively charged intestinal mucus, the adherence capacity of the encapsulated cells was investigated by in vitro adsorption test. The simplest model applied to investigate the adherence capacity of probiotic strains is by immobilization of commercially available pig mucin. The usage of PM, rich in MUC2, is advantageous due to the predominant expression of MUC2 in the large intestine, where colonization with probiotic bacteria preferably occurs, compared to in 
vitro models of different cell lines which are less abundant with MUC2 mucin, although better mimics the GI environment (Laparra and Sanz, 2009).

Low adsorption of PM on free cells surface (9.99 to $17.03 \%$ ) and excessive adsorption of PM on the surface of the $L$. casei 01 loaded microparticles $(51.87 \%$ to $68.81 \%)$ were observed in all buffers in the tested period of $24 \mathrm{~h}$ (Fig. 3 ). Adherence capacity values of $5.28 \pm 0.73,10.21 \pm 0.36$, $17.62 \pm 0.99$ and $31.07 \pm 1.02$ has been detected for $B$. bifidum, L. rhamnosus GG, B. lactis Bb12, and B. animalis, respectively, using in vitro model with crude mucin (type II) diluted in a phoshate-buffered solution ( $\mathrm{pH}$ 7.2) (Laparra and Sanz, 2009). With regard to these values, L. casei 01 possesses good adherence property. Muñoz-Provencio et al. (2009) have found high intra-species variability in adhesion properties using a collection of Lactobacillus casei strains from different origins, ranging from cheese isolates to commercial probiotics. The strains exhibited different binding levels to human colon fragments ex vivo which in the most cases had been found to correlate with the ability to in vitro binding of mucin. However, microencapsulation improved the adherence capacity, as significantly higher values $(\mathrm{p}<$ 0.05 ) for PM binding of $L$. casei 01 loaded microparticles compared to the free cells were obtained. Improvement of muco-adhesive characteristics of microparticles could be assigned primarily to the pseudoplastic behavior of increasing alginate concentrations (Kesavan et al., 2010) and pres- ence of charged or non-ionic functional groups in the structure of hydrophilic polymers able to form hydrogen bonds with mucosal surfaces (Khutoryanskiy, 2011). Further, chitosan as positively charged carrier may prolong the residence of encapsulated cells in the intestine by binding to the negatively charged glycoprotein from the mucus. A strong interaction between chitosan microspheres and mucin was detected in aqueous solution by turbidimetric measurements and biological studies confirmed that chitosan microspheres were retained in rat small intestine (He et al., 1998). Affinity of the prepared microparticles to attach to the intestinal mucus was confirmed with the positive surface charge of the chitosan-Ca-alginate microparticles (zeta potential, $+19.04 \pm 0.3 \mathrm{mV}$ ). Kim et al. (2008) reported no improvement in adhesion of microencapsulated L. acidophilus ATCC 43121 using alginate coating compared to nonencapsulated cells. The reason may be the specificity of the probiotic strain, cell sensitivity or changed muco-adhesive properties of alginate under conditions of atomization used for cell microencapsulation. No differences concerning adhesion ability to rat intestinal mucosa among free cells of $L$. casei ATCC 393 and immobilized ones using apple pieces have been found (Saxami et al., 2012). The rats were daily administered by fermented milk containing free or immobilized cells. However, it was reported that food matrix may affect surface properties and adhesion ability of lactic acid bacteria (Deepika and Charalampopoulos, 2010).

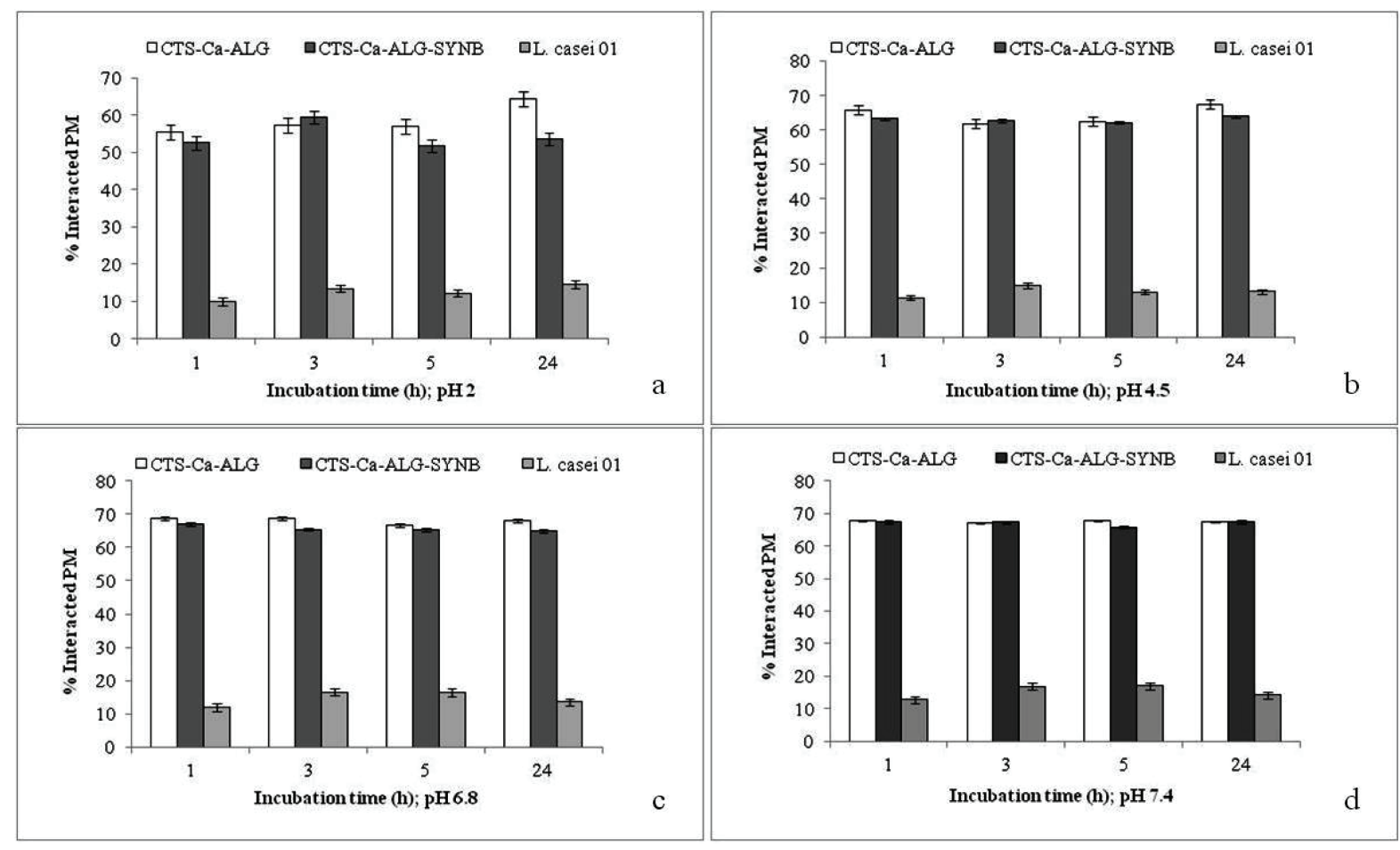

Fig. 3. Binding efficiency of pig mucin (PM) to free probiotic cells (L. casei 01), empty chitosan-Ca-alginate microparticles (CTS-Ca-ALG) and synbiotic chitosan-Ca-alginate microparticles (CTS-Ca-ALG-SYNB) in different buffer solutions: $\mathrm{pH} 2$ (a), pH 4.5 (b), $\mathrm{pH}$ 6.8, and $\mathrm{pH} 7.4$ during $24 \mathrm{~h}$ incubation period. 
No significant differences were found in adsorption of PM to empty and synbiotic microparticles under $\mathrm{pH} 2,4.5$, and 7.4 ( $\mathrm{p}>0.05)$, in our study. Only slight reduction in adsorption of PM to synbiotic microparticles compared to empty microparticles was observed in buffer solution with $\mathrm{pH}$ 6.8. These suggest that encapsulated cells did not negatively affect the muco-adhesion capacity of the polymer matrix. Insignificant changes of PM binding have been noticed during the whole incubation period of $1,3,5$, and 24 $h$ in each buffer $(p>0.05)$, thus the interactions of PM with free probiotic cells and/or microparticles were not dependant of the duration of incubation. After $24 \mathrm{~h}$ of incubation, the lowest adsorption of PM on the synbiotic microparticles was measured in $\mathrm{pH} 2(53.77 \pm 3.75 \%)$, while in $\mathrm{pHs} 4.5$, 6.8 , and 7.4 enhanced adsorption of $63.93 \pm 1,64.99 \pm 1.25$, and $67.45 \pm 0.63 \%$, respectively, was determined. The values for PM binding on the microparticles were increased with the increase of $\mathrm{pH}$, ranging from 2 to 7.4. These results are supported by the swelling of chitosan-alginate particles in weak acid and alkaline media accompanied with increased flexibility of the polymer chains which become capable to bind to mucus by hydrogen bonds, towards improved muco-adhesion. Increased PM binding in $\mathrm{pHs} 6.8$ and 7.4 indicated that synbiotic microparticles are able to retain in the lower GIT delivering viable probiotic cells, since adhesion is an important outcome for effective colonization by probiotics.

\section{Conclusion}

Oligofructose-enriched inulin added at the concentration of $1.5 \% \mathrm{w} / \mathrm{w}$ is an appropriate prebiotic to be used together with alginate and chitosan to microencapsulate $L$. casei 01 by spray-drying. The presence of the tested prebiotic was accompanied by enhancement of cell survival either during microencapsulation or cold storage of the encapsulated living cells, thus offering a potential as a functional ingredient to be applied in food products. In vitro enhanced PM binding to the L. casei 01 and oligofructose-enriched inulin loaded microparticles compared to free cells was detected. Correspondingly, synbiotic chitosan-Ca-alginate microparticles may provide favorable interaction with the negatively charged mucus glycoprotein, increase the muco-adhesion capacity of encapsulated probiotic and prolong the residence time in the lower intestine. Further research is required to study the adhesion to the large intestine in vivo and to prove the compatibility with a synbiotic effect.

\section{Acknowledgments}

This research was financially supported by the Ministry of Education and Science of the Republic of Macedonia (Project No. 13-3583/1). The authors would like to thank IMCD (UK) for the donation of sodium alginate (Protanal
10/60 LS, FMC BioPolymer, USA) and to Orafti Beneo Group and to IMCD (UK) for the donation of Orafti ${ }^{\circledR}$ Synergy 1 (L. Maréchal, Tienen, Belgium).

\section{References}

Almansa, C., Agrawal, A., Houghton, L.A., 2012. Intestinal microbiota, patophysiology and translation to probiotic use in patients with irritable bowel syndrome. Expert Rev. Gastroenterol. Hepatol. 6(3), 383-398.

Capela, P., Hay, T.K.C., Shah, N.P., 2006. Effect of cryoprotectants, prebiotics and microencapsulation on survival of probiotic organisms in yoghurt and freeze-dried yoghurt. Food Res. Int. 39, 203-211.

Charalampopoulos, D., Rastall, R.A., 2012. Prebiotics in food. Curr. Opin. Biotechnol. 23, 187-191.

Chen, S., Cao, Y., Ferguson, L.R., Shu, Q., Garg, S., 2013. Evaluation of mucoadhesive coatings of chitosan and thiolated chitosan for the colonic delivery of microencapsulated probiotic bacteria. J. Microencapsul. 30(2), 103-115.

Corcoran, B.M., Ross, R.P., Fitzgerald, G.F., Stanton, C., 2004. Comparative survival of probiotic lactobacilli spray-dried in the presence of prebiotic substances. J. Appl. Microbiol. 96, 1024-1039.

Deepika, G., Charalampopoulos, D., 2010. Surface and adhesion properties of lactobacilli. Adv. Appl. Microbiol. 70, 127-152.

Duncan, S.H., Flint, H.J., 2013. Probiotics and prebiotics and health in ageing populations. Maturitas 75(1), 44-50.

Fritzen-Freire, C.B., Prudêncio, E.S., Amboni, R.D.M.C., Pinto, S.S., Negrão-Murakami, A.N., Murakami, F.S., 2012. Microencapsulation of bifidobacteria by spray drying in the presence of prebiotics. Food Res. Int. 45, 306-312.

Fu, N., Chen, X.D., 2011. Towards a maximal cell survival in convective thermal drying processes. Food Res. Int. 44, 1127-1149.

Gentschew, L., Ferguson, L.R., 2012. Role of nutrition and microbiota in susceptability in inflammatory bowel disease. Mol. Nutr. Food Res. 56(4), 524-535.

Glavas Dodov, M., Calis, S., Crcarevska, M.S., Geskovski, N., Petrovska, V., Goracinova, K., 2009. Wheat germ agglutinin-conjugated chitosan-Ca-alginate microparticles for local colon delivery of 5-FU: development and in vitro characterization. Int. J. Pharm. 381, 166-175.

Gotteland, M., Andrews, M., Toledo, M., Munoz, L., Caceres, P., Anziani, A., Wittig, E., Speisky, H., Salazar, G., 2008. Modulation of Helicobacter pylori colonization with cranberry juice and Lactobacillus johnsonii La1 in children. Nutrition 24(5), 421-426.

He, P., Davis, S.S., Illum, L., 1998. In vitro evaluation of the mucoadhesive properties of chitosan microspheres. Int. J. Pharm. 166, 75-88.

ISAPP, 2008. $6^{\text {th }}$ Meeting of the International Scientific Association of Probiotics and Prebiotics. London, Ontario, Canada.

Kaplan, H., Hutkins, R.W., 2003. Metabolism of fructooligosaccharides by Lactobacillus paracasei 1195. Appl. Environ. Microbiol. 69, 2217-2222.

Kesavan, K., Nath, G., Pandit, J.K., 2010. Sodium alginate-based mucoadhesive system for gatifloxacin and its in vitro antibacterial activity. Sci. Pharm. 78(4), 941-957.

Khutoryanskiy, V.V., 2011. Advances in mucoadhesion and mucoadhesive polymers. Macromol. Biosci. 11(6), 748-764. 
Kim, S-J., Cho, S.Y., Kim, S.H., Song, O-J., Shin, I-S., Cha, D.S., Park, H.J., 2008. Effect of microencapsulation on viability and other characteristics in Lactobacillus acidophilus ATCC 43121. LWT-Food Sci. Technol. 41, 493-500.

Krasaekoopt, W., Watcharapoka, S., 2014. Effect of addition of inulin and galactooligosaccharide on the survival of microencapsulated probiotics in alginate beads coated with chitosan in simulated digestive system, yogurt and fruit juice. LWT-Food Sci. Technol. 57, 761-766.

Laparra, J.M., Sanz, Y., 2009. Comparison of in vitro models to study bacterial adhesion to the intestinal epithelium. Lett. Appl. Microbiol. 49, 695-701.

Macfarlane, S., Macfarlane, G.T., Cummings, J.H., 2006. Prebiotics in the gastrointestinal tract. Aliment. Pharmacol. Ther. 24, 701-714.

Makras, L., Van Acker, G., De Vuyst, L., 2005. Lactobacillus paracasei subsp. paracasei 8700:2 degrades inulin-types fructan exhibiting different degrees of polymerization. Appl. Environ. Microbiol. 71, 6531-6537.

Marteau P.R., de Vrese M., Cellier C.J., Schrezenmeir J., 2001. Protection from gastrointestinal diseases with the use of probiotics. Am. J. Clin. Nutr. 73, 430S-436S.

Meng, X.C., Stanton, S., Fitgerald, G.F., Daly, C., Ross, R.P., 2008. Anhydrobiotics: The challenge of drying probiotic cultures. Food Chem. 106, 1406-1416.

Mitropoulou, G., Nedovic, V., Goyal, A., Kourkoutas, Y., 2013. Immobilization technologies in probiotic food production. J. Nutr. Metab. 1-15, ID 716861.

Muñoz-Provencio, D., Liopis, M., Antolín, M., de Torres, I., Guarner, F., Pérez-Martínez, G., Monedero, V., 2009. Adhesion properties of Lactobacillus casei strains to resected intestinal fragments and components of the extracellular matrix. Arch. Microbiol. 191, 153-161.

Nazzaro, F., Fratianni, F., Coppola, R, Sada, A., Orlando, P., 2009. Fermentative ability of alginate-prebiotic encapsulated Lactobacillus acidophilus and survival under simulated gastrointestinal conditions. J. Funct. Foods 1, 319-323.

Nualkaekul, S., Deepika, G., Charalampopoulos, D., 2012. Survival of freeze dried Lactobacillus plantarum in instant fruit powders and reconstituted fruit juices. Food Res. Int. 48, 627-633.

Omar, J.M., Chan, Y., Jones, M.L., Prakash, S., Jones, P.J.H., 2013. Lactobacillus fermentum and Lactobacillus amylovorus as probiotics alter body adiposity and gut microflora in healthy persons. J. Funct. Foods 5, 116-123.

Orlando, A., Russo, F., 2012. Intestinal microbiota, probiotics and human gastrointestinal cancers. J. Gastrointest. Cancer 44(2), 121-131.
Peshev, D., Van den Ende, W., 2014. Fructans: prebiotics and immunomodulators. J. Funct. Foods 8, 348-357.

Petreska Ivanovska, T., Mladenovska, K., Kavrakovski, Z., Bogdanovska, L., Grozdanov, A., Popovski, E., PetrusevskaTozi L., 2012b. Effect of prebiotic content on functional and physicochemical properties on Lactobacillus casei loaded chitosan-Ca-alginate microparticles. Mac. Pharm. Bull. 58(1,2), 45-52.

Petreska Ivanovska, T., Petrushevska-Tozi, L., Grozdanov, A., Petkovska, R., Hadjieva, J., Popovski, E., Stafilov, T., Mladenovska, K., 2014a. From optimization of synbiotic microparticles prepared by spray-drying to development of new functional carrot juice. Chem. Ind. Chem. Eng. Quart. 20(4), 549-564.

Prakash, S., Tomaro-Duchesneau, C., Saha, S., Cantor, A., 2011. The gut microbiota and human health: an emphasis on the use of microencapsulated bacterial cells. J. Biomed. Biotechnol. 2-12.

Rößle, C., Brunton, N., Gormley, R.T., Ross, P.R., Butler, F., 2010. Development of potentially synbiotic fresh-cut apple slices. J. Funct. Foods 2, 245-254.

Sathyabama, S., Ranjith kumar, M., Bruntha devi, P., Vijayabharathi, R., Brindha devi, V., 2014. Co-encapsulation of probiotics with prebiotics on alginate matrix and its effect on viability in simulated gastric environment. LWT-Food Sci. Technol. 57, 419-425.

Saxami, G., Ypsilantis, P., Sidira, M., Simopoulos, C., Kourkoutas, Y., 2012. Distinct adhesion of probiotic strain Lactobacillus casei ATCC 393 to rat intestinal mucosa. Anaerobe 18, 417-420.

Soukoulis, C., Behboudi-Jobbehdar, S., Yonekura, L., 2014. Parmenter C., Stability of Lactobacillus rhamnosus GG in prebiotic edible films. Food Chem. 159, 302-308.

Tan, J., McKenzie, C., Potamitis, M., Thornburn, A.N., Mackay, C.R., Macia, L., 2014. The role of short-chain fatty acids in health and disease. Adv. Immunol. 121, 91-119.

Van Tassell, M.L., Miller, M.J., 2011. Lactobacillus adhesion to mucus. Nutrients 3, 613-636.

Watson, D., O'Connell Motherway, M., Schoterman, M.H.C., van Neerven, R.J.J., Nauta, A., van Sinderen, D., 2013. Selective carbohydrate utilization by lactobacilli and bifidobacteria. J. Appl. Microbiol. 114, 1132-1146.

Wickens, K., Black, P.N., Stanley, T.V., 2008. A differential effect of 2 probiotics in the prevention of eczema and atopy: a doble-blined, randomized, placebo-controlled trial. J. Allergy Clin. Immunol. 122, 788-794.

Yasmin, A., Butt, M.S., Afzaal, M., van Baak, M., Nadeem, M.T., Shahid, M.Z., 2015. Prebiotics, gut microbiota and metabolic risks: unveiling the relationships. J. Funct. Foods 17, 189-201. 


\title{
Резиме
}

\section{Влијание на инулин збогатен со олигофруктоза врз виталноста на микроинкапсулираниот Lactobacillus casei 01 и атхезивни својства на синбиотските микрочестички}

\author{
Тања Петреска Ивановска ${ }^{1}$, Зоран Живиќ ${ }^{1}$, Кристина Младеновска², Лидија Петрушевска-Този ${ }^{1 *}$

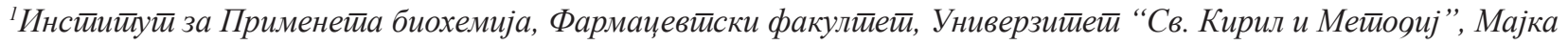 \\ Тереза 47, Скойје, Макеяонија

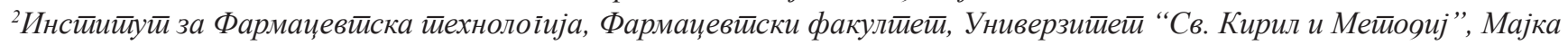 \\ Тереза 47, Скойје, Макеоонија
}

Клучни зборови: инулин збогатен со олигофруктоза, Lactobacillus casei, синбиотски микрочестички, муко-атхезија

Lactobacillus casei 01 беше ко-инкапсулиран со примена на различни концентрации на пребиотикот инулин збогатен со олигофруктоза за да се евалуира ефикасноста на пребиотикот во подобрување на пробиотската виталност во тек на микроинкапсулирање со сушење со распрснување и лиофилизирање. Притоа, беше следено и влијанието на пребиотикот врз стабилноста на инкапсулираните клетки при чување на $4{ }^{\circ} \mathrm{C}$ во тек на 8 недели. Атхезивноста на слободните клетки од L. casei 01 и микрочестичките со инкапсулирани клетки беше определена ин витиро со примена на муцин од желудник на прасе, заради проценка на улогата на микроинкапсулирањето во подобрување на атхезивните својства на L c casei 01 . Најголем степен на преживување на пробиотикот после подготовка со сушење со распрснување и лиофилизирање беше забележан кај микрочестичките подготвени со $3 \% \mathrm{M} / \mathrm{M}$ инулин збогатен со олигофруктоза, додека најголема стабилност на пробиотикот во тек на чување беше добиена кај микрочестичките подготвени со $1,5 \%$ м/м инулин збогатен со олигофруктоза. Ефикасноста во врзувањето на муцинот за микрочестичките беше значајно поголема во споредба со слободните пробиотски клетки во сите пуферски раствори што ги симулираат гастроинтестиналните услови во тек на инкубациониот период од $24 \mathrm{~h}$. Оттука, микроинкапсулирањето на $L$. casei 01 покрај подобрувањето на виталноста, може да обезбеди продолжен престој на пробиотските клетки во долниот интестинум како резултат на погодните муко-атхезивни својства на користените материјали за инкапсулирање. Добиените резултати покажуваат дека подготвените синбиотски цитозан-Са-алгинатни микрочестички претставуваат погоден систем за испорака на доволен број витални пробиотски клетки во долниот интестинум како целно ткиво за колонизација со пробиотици. 
